\title{
Opinions of Prospective Primary School Teachers about Methods and Techniques Suitable for Teaching Science: A Case Study from Turkey
}

\author{
Hülya Hamurcu ${ }^{1, *}$ \\ ${ }^{1}$ Buca Faculty of Education, Elementary Education Department, Primary Teacher Education Division, Dokuz Eylul \\ University, İzmir, Turkey \\ *Correspondence: Buca Faculty of Education, Elementary Education Department, Primary Teacher Education \\ Division, Dokuz Eylul University, İzmir, Turkey. E-mail: hulya.hamurcu@deu.edu.tr
}

Received: July 30, 2018

Accepted: September 16, $2018 \quad$ Online Published: December 7, 2018

doi:10.5430/wje.v8n6p21

URL: https://doi.org/10.5430/wje.v8n6p21

\begin{abstract}
The aim of this study was to determine opinions of a group of prospective Turkish primary school teachers about what teaching methods and techniques are more suitable to teach science. In addition, their perceived competence in selection of teaching methods and techniques was explored. In Turkey, primary school teachers offer various courses in the first four years of primary education. Their ability to benefit from teaching methods and techniques suitable for subjects and courses is considered important in terms of realization of learning. The study was also directed towards examining whether third-year university students having taken courses for methods and techniques used to teach different subjects felt competent about selection of suitable methods and techniques.

This is a case study using both quantitative and qualitative research methods. Quantitative data were gathered with Perceived Competence Scale for Selection of Teaching Methods and Techniques for Prospective Teachers, developed by Durdukoca et al. (2017). Qualitative data were collected through an open-ended question "What teaching methods and techniques do you think you want to use in the future". All the participants answered this open-ended question and completed the scale. Data obtained through the open ended-question were analyzed with content analysis.

The study sample included 96 third-year students studying in the Department of Primary Education in Buca Education Faculty of Dokuz Eylül University in the spring term of the 2017-2018 academic year. Quantitative data were analyzed with SPSS v. 22 and t-test.

The prospective primary school teachers were found to plan to use student-centered methods and techniques and to have high perceived competence concerning selection of teaching methods and techniques. Their perceived competence did not differ between genders and students with different academic performance. Only having a positive perception of competence significantly differed between branches of students.
\end{abstract}

Keywords: prospective primary school teachers, methods and techniques of teaching science, perceived competence in selection of teaching methods and techniques

\section{Introduction}

Effectiveness of teaching methods and techniques in learning has been one of the issues dealt with in educational research. Studies on effectiveness of learning strategies, teaching methods and techniques in individuals' learning have yielded different results. Most of the studies have revealed that using different methods and techniques creates positive effects on various factors. Teaching methods and techniques utilized in teaching science, Turkish and social sciences etc. have been found to be effective in predetermined variables (Canbulat, 2016; Cantürk Günhan \& Başer, 2008; Kuşçu, 2017; Memiş \& Erdem, 2013; Özyılmaz, Akamca \& Hamurcu, 2005; Özyılmaz Akamca \& Hamurcu, 2009; Susar Kırmız1, 2007; Şahbaz \& Hamurcu, 2012, Sayan \& Hamurcu, 2018).

Description and classification of teaching methods and techniques have been frequently studied issues in the literature (Çalışkan, Karadağ \& Çalışkan, 2010; Demirel, 2002; Gözütok, 2006; Sönmez, 2004; Taşpınar, 2016). Teachers should be able to select suitable methods and techniques after they decide what subjects they will teach and what gains they will attain. It is also known that students' active involvement in the learning process is of importance 
(Açıkgöz-Ün, 2003). With recent changes in learning approaches in Turkey (cognitive learning, constructivist learning, research-questioning-based learning and argumentation-based learning etc.), student centered learning methods and techniques have played more frequent roles in learning processes. Since this study is about teaching science, it is important that teaching methods and techniques should be determined and taught to prospective teachers especially in accordance with changes experienced in curricula for science courses between 2013 and 2017. It has been emphasized in the curricula (MEB, 2013:III \& MEB, 2017:11-12) that learning environments in which students can become active such as learning based on problems, projects, argumentation and cooperation should be created.

However, studies about prospective teachers' selection of teaching methods and techniques have revealed conflicting results. In a study by Doğan (2003) about teaching techniques preferred by primary school teachers, the most frequently used technique was found to be question-answer followed by direct instruction, discussion and problem solving. In a study by Taşkaya and Muşta (2008) on opinions of 244 primary school teachers about methods used to teach Turkish, the most frequently known and used techniques were question-answer, drama and direct instruction. Soylu (2009) investigated abilities of last-year students studying primary education to utilize methods and techniques in math courses. The researcher found that most of the students felt competent or partly competent in the techniques direct instruction, giving definitions and rules and question-answer, but felt incompetent in constructivist methods and techniques, discovery, cooperative methods and techniques, demonstration, games, case studies and problem creation and solution.

Şimşek, Hırça and Coşkun investigated selection and use of teaching methods and techniques in science teachers and reported similar results (2012). The teachers were found to prefer traditional methods like question-answer and direct instruction to such methods as projects, tours-observations and use of a computer or a microscope. In a study by Özer (2013) on 381 last-year students in education faculties, the students were found to know about most of teaching methods and techniques considered important to implementation of active and constructivist learning, but prefer to use such methods and techniques as direct instruction and question-answer.

Şahin and Güven (2016) performed a study using a semi-structured interview on 20 primary school teachers to reveal their opinions about methods and techniques utilized in science, life sciences and social sciences classes. They reported that the teachers generally adopted direct instruction, question-answer, tours-observations, case reports and brainstorming. The teachers were also found to benefit from different material, activities and technological equipment.

Yıldırım, Köklükaya and Aydoğdu (2016) carried out a study using a semi-structured interview on 183 second-year students in the Department of Science Education in Education Faculty of Gazi University to determine the methods and the techniques they selected and to investigate causes of their selections in science units. They reported that the students more frequently preferred traditional teaching methods and techniques such as direct instruction and question-answer in physics, chemistry and biology units. Eskici (2018) in a qualitative study with 38 prospective teachers receiving pedagogical formation courses at Kurklareli University examined methods and techniques the participants wanted to use most frequently during their prospective teaching career. The methods and the techniques the participants most frequently preferred to use were brain storming, educational games, question-answer, six thinking hats technique, discussions, role plays, case studies and concept mapping. The participants also emphasized that these student-centered methods and techniques are fun to use and beneficial in creation of a good learning environment. They also noted that the abovementioned methods and techniques encouraged students to become active and helped them to learn by experiencing things.

It seems that although both teachers and prospective teachers point out to positive effects of using student-centered methods and techniques, they generally select traditional/behavioral methods and techniques and do not adopt modern ones much. It can be explained by the fact that prospective teachers select methods and techniques similar to those they are exposed to in their preservice education (Altıparmak \& Nakipoğlu, 2004; Bozpolat, Uğurlu, Usta, \& Şimşek, 2016; İlter, 2014).

So that prospective teachers can implement different teaching methods and techniques after their graduation, the first thing to do is that causes of their preferences should be determined. In addition, it is important that perceived competence of prospective primary school teachers about their selection of teaching methods and techniques should be determined and that they should be recommended different activities based on their perceived competence.

The aim of this study is to reveal opinions of prospective primary school teachers concerning what teaching methods and techniques they will use and their perceived competence in selection of the methods and the techniques. Based on these aims, answers to the following research questions were sought: 
1. What do prospective primary school teachers think about the methods and techniques they will prefer to teach science?

2. What are the degrees of general, positive and negative perceived competence of the prospective primary school teachers in selection of teaching methods and techniques?

3. Do prospective teachers' positive and negative perceptions of competence in selection of teaching methods and techniques differ in terms of their gender, branch and academic performance?

4. Do prospective teachers' general perceptions of competence in selection of teaching methods and techniques differ in terms of gender, branch and academic performance?

\section{Methods}

This is a case study, which allows noticing and describing details of a phenomenon (Büyüköztürk et al. 2008: 249-250). Variety in data was achieved by collecting both qualitative and quantitative data. Qualitative data were collected by asking an open-ended question and the students' responses to this question were analyzed with content analysis. Quantitative data were obtained through the survey method. It is defined as a quantitative research method which allows making numerical descriptions of attitudes, tendencies or opinions of a population by studying a sample of that population (Creswell, 1998; Fowler, 2009). Therefore, a questionnaire was used for data collection.

\subsection{Study Sample}

The study sample included all third-year students studying in the Department of Primary Education in Buca Education Faculty in the spring term of 2017-2018 academic year $(n=96)$. The fact that the researcher was working in the study setting facilitated data collection. Towards the end of the spring term, the students both answered the open-ended question and responded to the questionnaire voluntarily. Characteristics of the sample are shown in Table 1.

Table 1. Characteristics of the Study Sample

\begin{tabular}{lllll}
\hline Characteristics & & Number/Percentage & Total \\
\hline Gender & Female & 73 & $76 \%$ & 96 \\
& Male & 23 & $24 \%$ & \\
Branch & 3 A & 46 & 96 \\
& $3 \mathrm{~B}$ & 50 & & 96 \\
Academic Performance & Up to 3.00 & 73 & $76 \%$ & \\
(GPA) & & & & \\
& 3.01 and higher than 3.01 & 23 & $24 \%$ & \\
\hline
\end{tabular}

As shown in Table 1, the number of the female students was higher, which is consistent with the results of the studies conducted in the same study setting in previous years (Yaprak, Armağan \& Hamurcu, 2014; Hamurcu, 2018). It may be that females more frequently prefer to become a primary school teacher in Turkey.

\subsection{Data Collection Tools}

Data collection was performed by using Perceived Competence Scale for Selection of Teaching Methods and Techniques for Prospective Teachers, developed by Durdukoca et al. (2017). It is a five-point Likert scale and involves two subscales and 22 items. One subscale is called positive perceptions about competence in selection of techniques and is composed of 15 items. The other subscale is called negative perceptions about competence in selection of techniques and involves seven items.

The highest and the lowest scores for the scale are 110 and 22 respectively. Ranges of scores were determined to interpret mean values (Durdukoca et al., 2017:408). Ranges of scores for the first subscale were interpreted as in the following: 15-27 (very low), 27.1-39 (low), 39.1-51 (moderate), 51.1-63 (high) and 63.1-75 (very high). Ranges of scores for the second subscale were interpreted as follows: 29.5-35 (very low), 23.7-29.4 (low), 18.2-23.6 (moderate), 12.6-18.1 (high) and 7-12.5 (very high). The items in the second subscale were scored in the reverse order since it generally includes negative statements. Ranges of total scores likely to be obtained from the scale were similarly determined (22-39.5, 39.6-57.1, 57.2-74.8, 74.9-92.4 and 92.5-110).

According to results of a reliability analysis made by Durdukoca et al., who developed the scale (2017:407), Cronbach alpha was .90 for the scale. It was found to be .88 in the present study. Cronbach alpha was found to be .85 
for positive perceptions of competence and .82 for negative perceptions of competence. These Cronbach values for the subscales seemed to be a little lower than those reported for the original scale. Hamurcu and Canpulat, who performed a similar study on 321 fourth-year students (2018), reported that Cronbach alpha was .91 for the scale, .92 for positive perceptions about competence and .89 for negative perceptions about competence. Decreased Cronbach alpha values in the present study can be due to the small sample size $(\mathrm{n}=96)$. However, the scale can still be considered as very reliable. As Özdamar (1997) and Alpar (2003) reported, the scales having Cronbach alpha ranging between .60 and .80 are considered quite reliable and those having Cronbach alpha ranging between .80 and 1.00 are considered as very reliable. As a result, data obtained in the present study can be regarded as reliable.

Quantitative data obtained through the scale were analyzed by using SPSS 22 and t test and descriptive statistics. $\mathrm{p}<.05$ was considered as significant.

In addition to administration of a scale, the students were also asked to answer an open-ended question "What methods and techniques will you, as a primary school teacher, use to teach science in the future? and why?". They were asked to put the methods and techniques they will use in order from one to five and explain them briefly. Responses to this question were analyzed with content analysis (Yıldırım \& Şimşek, 2000:162) by the researcher. The results of the analysis was checked by another lecturer and reliability of the analysis was achieved.

\section{Results}

This section presents the results of the analysis of data obtained through an open-ended question and the scale Perceived Competence Scale for Selection of Teaching Methods and Techniques for Prospective Teachers. The most frequently preferred methods and techniques based on the data from responses to the open-ended question and their frequencies are outlined in a table. The order of the students' preferences was also documented during analysis; however, it was not given in the table due to difficulty in its tabulation.

Question 1. What do prospective primary school teachers think about the methods and techniques they will prefer to teach science?

As shown in Table 2, the participants classified the methods and techniques into different categories. It can be explained by the fact that the researcher utilized similar classifications in the courses Science and Technology I and II throughout the second semester. Several sources about teaching principles and methods have shown that some techniques are considered as schematized (e.g. concept mapping). As emphasized in the literature, concept maps (Novak, 1984; Korkmaz, 2004; Eskici, 2018), mind maps (Buzan, 2003, Evrekli \& Balım, 2010) and concept cartoons (Kabapınar, 2005; Evrekli, İnel \& Çite, 2006; Özyllmaz Akamca \& Hamurcu, 2009; Naylor \& Keogh, 2011) are used not only as teaching methods and techniques but also assessment and evaluation tools. How often the participants preferred to utilize these was also given in the table. In addition, two learning theories, i.e. constructivism and multiple intelligence were presented under the heading theories. The participants mentioning these theories noted that they would adopt them while conducting classes. However, they did not mention any specific teaching methods and techniques. It should be kept in mind that student-centered teaching methods and techniques have to be employed more frequently while both theories are put into practice (Saban, 2001; Şelçuk, Kayll \& Okut, 2002). The orders in the table should be interpreted in light of the abovementioned explanations.

As shown in the table, the methods and the techniques most frequently preferred by the prospective primary school teachers to teach science were drama, experiment, cooperative learning, question-answer, tour and observation. This was a favorable finding. It is known that most of these methods and techniques are student-centered and enable students to be active. There have been several studies showing their importance in the educational process. Açikgöz Ün (2002:131-145) noted that educational games, mind maps, conceptual network and brainstorming are active learning techniques. Similarly, Bilen emphasized the role of educational games (1996:148-165) and the teaching methods and techniques which can be implemented outside the class like tours and observations in the learning process. Açıkgöz Ün (1992: 115-117 \& 2002:171-220) underlined positive effects of cooperative learning on the learning process. In addition, many sources based on theoretical work and results of interventional studies have shown benefits of drama in teaching (Üstündăg, 2000; MEB, 2003; Önder, 2003; Susar Kırmızı, 2007; İçelli, Polat \& Sülün, 2008; Adıgüzel, 2013). There have also been studies explaining characteristics of POE techniques, recently reported to be constructivist learning methods, and how they can be implemented (Atasoy, 2004: 171-224) and investigating their benefits in practice (Özyılmaz Akamca \& Hamurcu, 2009: 1186-1206; Köklükaya \& Yıldırım, 2018). 
Table 2. The Results of the Analysis of the Participants' Preferences Concerning Methods and Techniques to Teach Science $(\mathrm{N}=96)$

\begin{tabular}{|c|c|c|c|c|}
\hline Order & Methods and Techniques & $\begin{array}{l}\text { Branch 3A } \\
\text { (f) }\end{array}$ & $\begin{array}{l}\text { Branch 3B } \\
\text { (f) }\end{array}$ & $\begin{array}{l}\text { Total } \\
\text { (f) }\end{array}$ \\
\hline 1 & Drama & 28 & 32 & 60 \\
\hline 2 & Experiment & 20 & 34 & 54 \\
\hline 3 & Cooperative learning & 26 & 23 & 49 \\
\hline 4 & Question-Answer & 16 & 20 & 36 \\
\hline 5 & Observation & 9 & 22 & 31 \\
\hline 6 & Tour & 5 & 18 & 23 \\
\hline 7 & Discussion & 9 & 14 & 23 \\
\hline 8 & Brainstorming & 7 & 15 & 22 \\
\hline 9 & Problem-based learning & 9 & 3 & 12 \\
\hline 10 & Analogy & 9 & 2 & 11 \\
\hline 11 & Direct instruction & 6 & 5 & 11 \\
\hline 12 & Storifying & 0 & 11 & 11 \\
\hline 13 & Argumentation-based learning & 7 & 1 & 8 \\
\hline 14 & Educational games & 1 & 5 & 6 \\
\hline 15 & Project-based learning & 4 & 1 & 5 \\
\hline 16 & Presentations by using a computer & 3 & 2 & 5 \\
\hline 17 & Please talk and pass & 2 & 2 & 4 \\
\hline 18 & Station Technique & 4 & 0 & 4 \\
\hline 19 & Learning by doing and discovering & 2 & 2 & 4 \\
\hline 20 & TAGA/Prediction, Observation and explanation (POE) & 2 & 1 & 3 \\
\hline 21 & Simulation & 0 & 2 & 2 \\
\hline 22 & Writing a conclusion statement & 0 & 2 & 2 \\
\hline 23 & Group work & 1 & 1 & 2 \\
\hline 24 & Socratic questioning & 0 & 1 & 1 \\
\hline 25 & Learning window in the class & 0 & 1 & 1 \\
\hline 26 & BSB use & 1 & 0 & 1 \\
\hline Order & Schematized tools & $\begin{array}{l}\text { Branch 3A } \\
\text { (f) }\end{array}$ & Branch 3B (f) & $\begin{array}{l}\text { Total } \\
\text { (f) }\end{array}$ \\
\hline 1 & Structured grid & 11 & 8 & 19 \\
\hline 2 & Concept map & 7 & 2 & 9 \\
\hline 3 & Semantic analysis table (SAT) & 0 & 8 & 8 \\
\hline 4 & Mind map & 6 & 2 & 8 \\
\hline 5 & Concept cartoon & 4 & 3 & 7 \\
\hline 6 & Fishbone diagram & 5 & 0 & 5 \\
\hline 7 & Conceptual network & 2 & 2 & 4 \\
\hline 8 & Vee diagram & 2 & 0 & 2 \\
\hline 9 & Information map & 0 & 2 & 2 \\
\hline 10 & Diagnostic tree (DT) & 1 & 0 & 1 \\
\hline \multirow[t]{2}{*}{11} & Venn diagram & 1 & 0 & 1 \\
\hline & Theories & & & \\
\hline 1 & Multiple intelligence & 14 & 3 & 17 \\
\hline 2 & Constructivism & 4 & 0 & 4 \\
\hline
\end{tabular}

Tools and techniques classified as schematized tools have been shown to be utilized in learning processes. Concept maps, concept cartoons and mind maps have become widespread recently (Özyılmaz Akamca, Ellez, \& Hamurcu, 2009; Evrekli, İnel, \& Balım, 2011; Yılmaz Korkut \& Şaşmaz Ören, 2018).

Based on the information presented in the table, it can be suggested that methods, techniques and schematized tools are likely to be adopted by teachers to teach science in the future.

Question 2: What are the degrees of general, positive and negative perceived competence of the prospective primary school teachers in selection of teaching methods and techniques? 
Results of descriptive statistics for the prospective primary school teachers' perceived competence in selection of teaching methods and techniques are shown in Table 3.

Table 3. Results of Descriptive Statistics for Data from Perception Scale for Prospective Primary School Teachers' Competence in Selection of Teaching Methods and Techniques

\begin{tabular}{|c|c|c|c|c|c|c|}
\hline Variables & $\mathbf{N}$ & $\overline{\bar{x}}$ & SS & Median & Range & $\begin{array}{l}\text { Minimum and } \\
\text { Maximum Values }\end{array}$ \\
\hline $\begin{array}{l}\text { Positive Perceptions of } \\
\text { Competence }\end{array}$ & 96 & 65.89 & 5.64 & 66.00 & 22.00 & $53-75$ \\
\hline $\begin{array}{l}\text { Negative Perceptions of } \\
\text { Competence }\end{array}$ & 96 & 30.44 & 3.57 & 30.00 & 15.00 & $20-35$ \\
\hline $\begin{array}{l}\text { Total Perceptions of } \\
\text { Competence }\end{array}$ & 96 & 96.32 & 7,97 & 97.00 & 31.00 & $79-110$ \\
\hline
\end{tabular}

As presented in Table 3, the scores for positive perceptions of competence ranged from 53 to 75 . However, the range can be $17-75$. The mean score $(\overline{\boldsymbol{x}}=65.89)$ also suggests that the prospective primary school teachers had very high levels of positive perceptions about their competence. The scores 63.1-75 were reported to show high positive perceptions of competence (Durdukoca et al., 2017:408).

Scores for negative perceptions of competence may range from 7 to 35 . As shown in the table, the participants got the scores 20-35. The mean score for negative perceptions of competence $(\overline{\boldsymbol{x}}=30.44)$ also suggests that the participants had low negative perceptions of competence. The items in the subscale negative perceptions of competence are scored in the reverse order and high scores indicate positive perceptions. The scores 29.5-35 were reported to show very low negative perceptions (Durdukoca et al., 2017:408). As a result, the prospective primary school teachers thought they were sufficiently competent in selection of methods and techniques.

Total scores for competence in selection of methods and techniques may vary from 22 to 110 . The scores of the participants in this study ranged from 79 to 110 . The mean total score was 96.32. It is clear that the participants got very high levels of perceived competence. The range of total scores 92.5-110 was reported to be very high (Durdukoca et al., 2017:408). It is clear that the prospective primary school teachers were quite competent in selection of methods and techniques.

Question 3: Do prospective teachers' positive and negative perceptions of competence in selection of teaching methods and techniques differ in terms of their gender, branch and academic performance?

The results of $t$ test used to seek an answer to this question are shown in Table 4 and Table 5 since it can be more appropriate to present the results about positive and negative perceptions of competence separately. The students were divided into two groups based on their academic performance, i.e. grade point average. Those with a GPA of 2.00-3.00 were assigned into Group 1 and those with a GPA of 3.01-4.00 were assigned into Group 2.

Table 4. Results of $t$ Test for Positive Perceptions of Competence in Selection of Teaching Methods and Techniques

\begin{tabular}{llcccccc}
\hline Variables & Aritmethic Mean & $\mathbf{N}$ & $\overline{\boldsymbol{x}}$ & $\mathbf{S S}$ & $\mathbf{S d}$ & $\mathbf{t}$ test & $\mathbf{p}$ \\
\hline Gender & Female & 73 & 66.16 & 5.53 & 94 & .863 & .390 \\
& Male & 23 & 65.00 & 5.99 & & & \\
Branch & 3 A & 46 & 67.20 & 5.29 & 94 & 2.23 & $\mathbf{. 0 2 8 *}$ \\
& 3 B & 50 & 64.68 & 5.73 & & & \\
Academic & GPA of 2.00-3.00 & 73 & 65.50 & 5.60 & 94 & -1.637 & .226 \\
Performance & GPA of 3.01-4.00 & 23 & 67.13 & 5.72 & & & \\
\hline
\end{tabular}

$* \mathrm{p}<0.05$ was considered as significant.

As presented in the table, the prospective primary school teachers had high levels of positive perceptions of competence regardless of all the variables. Although the mean values were close to each other, there was a significant difference between the branches $(\mathrm{p}=.028, \mathrm{p}<.05)$. This significant difference was in favor of the branch 3 A. This might have resulted from internal dynamics of the branch. There was not a significant difference in positive perceptions of competence in terms of gender and academic performance. 
Table 5 shows findings concerning negative perceptions of competence.

Table 5. Results of $t$ Test for Negative Perceptions of Competence in Selection of teaching Methods and Techniques

\begin{tabular}{llcccccc}
\hline Variables & Aritmethic Mean & $\mathbf{N}$ & $\overline{\boldsymbol{x}}$ & $\mathbf{S S}$ & $\mathbf{S d}$ & $\mathbf{t}$ test & $\mathbf{p}$ \\
\hline Gender & Female & 73 & 30.62 & 3.54 & 94 & .874 & .385 \\
& Male & 23 & 29.87 & 3.68 & & & \\
Branch & 3 A & 46 & 30.65 & 3.41 & 94 & .575 & .563 \\
& 3 B & 50 & 30.24 & 3.74 & & & \\
Academic Performance & GPA of 2.00-3.00 & 73 & 30.10 & 7.84 & 94 & -1.686 & .095 \\
& GPA of 3.01-4.00 & 23 & 31.52 & 8.11 & & & \\
\hline
\end{tabular}

The data analysis showed that the prospective primary school teachers had very low levels of negative perceptions of competence in selection of teaching methods and techniques. Since the items are scored in the reverse order, the participants did not have negative perceived competence at moderate or high levels and their perceived negative competence did not differ significantly in terms of gender, branch or academic performance. In fact, the mean values of all the groups were quite close to each other. As a result, the prospective primary school teachers felt competent in their selection of teaching methods and techniques.

Question 4. Do prospective teachers' general perceptions of competence in selection of teaching methods and techniques differ in terms of gender, branch and academic performance?

In an attempt to answer this question, the total scores for the responses of the students to the scale for selection of teaching methods and techniques were analyzed and compared in terms of gender, branch and academic performance and general status was revealed. Obtained results are shown in Table 6.

Table 6. Results of $t$ Test for Total Scores for Perceptions of Competence in Selection of Teaching Methods and Techniques

\begin{tabular}{llcccccc}
\hline Variables & Aritmethic Mean & $\mathbf{N}$ & $\overline{\boldsymbol{x}}$ & $\mathbf{S S}$ & $\mathbf{S d}$ & $\mathbf{t}$ test & $\mathbf{p}$ \\
\hline Gender & Female & 73 & 96.78 & 7.72 & 94 & 1.003 & .319 \\
& Male & 23 & 94.87 & 8.74 & & & \\
Branch & 3 A & 46 & 97.85 & 7.57 & 94 & 1.819 & .072 \\
& 3 B & 50 & 94.92 & 8.14 & & & \\
Academic & GPA of $2.00-3.00$ & 73 & 95.59 & 7.84 & 94 & -1.621 & .108 \\
Performance & GPA of 3.01-4.00 & 23 & 98.65 & 8.11 & & & \\
\hline
\end{tabular}

As seen in the table above, no significant difference was found in total scores for perceptions of competence in selection of teaching methods and techniques in terms of gender, branch and academic performance. The finding that the mean values were very close to each other can explain this lack of a significant difference. In general, the prospective primary school teachers had high levels of perceived competence in selection of teaching methods and techniques.

\section{Conclusions and Recommendations}

The present study was performed to reveal opinions of prospective primary school teachers about what methods and techniques they found suitable to teach science and to determine their perceptions of competence in selection of these methods and techniques. The participants thought that they would most frequently benefit from student-centered teaching methods and techniques like dramas, experiments, cooperative learning, question-answer, tours and observations, which is consistent with the results of a study by Eskici (2018). Similarly, in a study by Böyük et al., the science teachers emphasized that they could benefit from laboratory practices to encourage students to participate in classes (Böyük, Demir, \& Erol, 2010). In addition, Kaptan and Kuşakçı underlined effectiveness of brainstorming (2002). It has also been reported that educational games (Saracaloğlu \& Karademir, 2009) and drama are effective in different aspects of the learning process (Başçı \& Gündoğdu, 2011; Yılmaz, 2013). To sum up, prospective teachers' adoption of student-centered teaching methods and techniques seems to be promising in terms of practices in the future.

The current study was also directed towards examining the prospective primary school teachers' perceived 
competence in selection of teaching methods and techniques. The results showed that they had high levels of perceived competence. These perceptions did not significantly differ between males and females and between students with different levels of academic performance. However, positive perceptions of competence were significantly different between the branches. Since there have not been many studies about this issue in Turkey, the results of the present study were compared with those reported by Hamurcu and Canbulat (2018). They performed a study with 321 prospective primary school, Turkish, social sciences and preschool teachers and reached similar results. All the prospective teachers had higher levels of perceived competence in selection of methods and techniques. Although academic performance did not create a significant difference, gender and branches caused a significant difference. This difference resulted from the female students and the students who would become primary school teachers. The reason for the lack of a significant difference in the present study might have been due to the fact that all the students belonged to the same branch and that the sample size was small.

Based on the results of this study, the prospective primary school teachers plan to utilize student-centered teaching methods and techniques in general and have high levels of perceived competence in selection of these methods and techniques. It is important that they reported to select teaching methods and techniques which will improve creativity, communication, collaboration and critical thinking considered as the skills of the $21^{\text {st }}$ century.

The finding that the prospective primary school teachers preferred to adopt student-centered methods and techniques to teach science like drama, experiment, observation and cooperative learning is favorable since it can create positive effects on the learning environment. Their high perceived competence in selection of teaching methods and techniques can also be an indicator for these positive effects. The role of effective and positive interactions which can be created by teachers in learning make the results of this study more valuable.

In light of the results of the study, the following recommendations can be made:

1- Although the prospective primary school teachers want to adopt student-centered teaching methods and techniques, newly developed approaches such as STEM (Science, Technology, Engineering and Mathematics) should be incorporated into the learning process.

2- The prospective primary school teachers were found to have high perceived competence in selection of teaching methods and techniques. Attempts to improve their competence should be continued. Incorporation of alternative practices in the learning process could be more effective.

3- Due to recent regulations about education faculties, some restrictions are experienced in courses. In accordance with the new program to be initiated for the first-year students, the course Drama offered for four hours per week in the past will be given for two hours a week and the course Teaching Science, offered for two terms in the past, will be offered for one term only. As revealed by the responses to the open-ended question, the prospective teachers adopted drama as a teaching method and reported to implement it. However, decreased course hours may affect the content and effectiveness of the course. Likewise, forming the basis of the present study and given three hours weekly for two terms in the past, the course Teaching Science was limited to one term. This may have a negative effect on its content and practice and may remain insufficient. In fact, the weekly course hours had been reduced from four to three before, which had created problems. Offering the course only in a single term can cause difficulty in achieving the sequence of course contents. The new program has not been initiated for the third-year students yet and it is expected that these problems can be eliminated.

4- There have been few studies about perceived competence in selection of teaching methods and techniques. Therefore, the results of the present study could provide guidance for further studies.

5- The sample of the present study included prospective primary school teachers only at one university. It can be recommended that further studies having larger sample sizes, including students from several universities and using different research methods should be conducted.

\section{References}

Açıkgöz Ün, K. (1992). Işsbirlikli öğrenme kuram araştırma ve uygulama. Malatya: Uğurel Matbaası.

Açıkgöz Ün, K. (2002). Aktif öğrenme. Malatya: Eğitim Dünyası yayınları.

Adgüzel, Ö. (2013). Eğitimde yaratıcı drama (3rd ed.). Baskı, Ankara: PEGEM A akademi.

Altıparmak, M., \& Nakipoğlu, M. (2004). Biyoloji öğretmen adaylarının öğretim elemanlarının uyguladıkları öğretim yaklaşımları hakkındaki görüşleri. Buca Eğitim Fakültesi Dergisi, 15, 101-107. 
Atasoy, B. (2004). Fen öğrenimi ve öğretimi (2nd ed.). Bask1, Ankara: Asil yayın dağııtım.

Başçı, Z., \& Gündoğdu, K. (2011). Öğretmen adaylarının drama dersine ilişkin tutumları ve görüşleri: Atatürk üniversitesi örneği. İlköğretim Online, 10(2), 454-467.

Bilen, M. (1996). Plandan uygulamaya ögretim. Ankara: Aydan WEB tesisleri.

Böyük, U., Demir, S., \& Erol, M. (2010). Fen ve teknoloji dersi öğretmenlerinin laboratuvar çalışmalarına yönelik yeterlilik görüşlerinin farklı değişkenlere göre incelenmesi. TÜBAV Bilim Dergisi, 3(4), 342-349.

Bozpolat, E., Uğurlu, C. T., Usta, H. G., \& Şimşek, A. S. (2016). Öğrenci ve öğretim elemanlarının öğretim yöntem ve tekniklerine iliş̧in görüşleri: Nitel bir araştırma. Dicle Üniversitesi Ziya Gökalp Eğitim Fakültesi Dergisi, 27, 83-95. http://dx.doi.org/10.14582/DUZGEF.690

Büyüköztürk, Ş., Çakmak Kılıç, E., Akgün, E., Ö, Karadeniz, Ş., \& Demirel, F. (2008). Bilimsel Araştırma Yöntemleri, Geliştirilmiş 11. Bask1, Ankara: PEGEM A Akademi.

Buzan, T. (2003). Yaratıcı Zekanın Gücü. Çev; Beyhan Kurt. İstanbul: Epsilon yayıncılık.

Çalışkan, N., Karadağ, E., \& Çalışkan, F. N. (2010). Eğitim, iletişim ve öğretmenin beden dili (2nd ed.). Bask1.Ankara: Kök yayıncılık.

Canbulat, T. (2016). Beyin Uyumlu Öğrenme Yaklaşımının İlköğretim Beşinci Sınıf Sosyal Bilgiler Dersinde Öğrencilerin Yönetici İşlevlerine Etkisi, International Journal of Active Learning (IJAL), 1(1), 29-48.

Cantürk Günhan, B., \& Başer, N. (2008). Probleme dayalı öğrenme yönteminin öğrencilerin matematiğe yönelik tutumlarına ve başarılarına etkisi. Abant İzzet Baysal Üniversitesi Eğitim Fakültesi Dergisi, 8(1), 119-134.

Creswell, J. W. (1998). Qualitative inquiry and research design: Choosing among five traditions. Thousand Oaks, CA: Sage Publications.

Demirel, Ö. (2002). Öğretme sanatı (3rd ed.). Baskı. Ankara: PEGEM A yayıncılık.

Doğan, C. (2003). Sınıf öğretmenlerinin derslere ilişkin görüşleri ve tercih ettikleri öğretim yöntemleri (İstanbul örneği). İ.Ü. Illahiyat Fakültesi Dergisi, 8, 31-48.

Durdukoca, F. Ş., Yardımciel, E., Beşeren, H., \& Özbek, S. (2017). The perception scale of teachers' applicants capacity to choose teaching technics. Electronic Journal of Social Sciences, 16(61), 397-411.

Eskici, M. (2018). Teacher candidates' opinions about instructional methods and techniques. International Journal of Quality in Education (IJQE), 2(1), 48-65.

Evrekli, E., \& Balım, A. G. (2010). Fen ve teknoloji öğretiminde zihin haritası ve kavram karikatürü kullanımının öğrencilerin akademik başarılarına ve sorgulayıcı öğrenme becerileri algılarına etkisi. Batı Anadolu Eğitim Bilimleri Dergisi, 1(2), 76-98.

Evrekli, E., İnel, D., \& Balım, A. G. (2011). Fen öğretiminde zihin haritaları ve kavram karikatürleri birlikte kullanımının etkileri üzerine bir çalışma. Necatibey Eğitim Fakültesi Elektronik Fen ve Matematik Eğitimi Dergisi, 5(2), 58-85.

Evrekli, E., İnel, D., \& Çite, S. (2006). Yapılandırmacı yaklaşım temelinde Fen ve teknoloji öğretiminde kavram karikatürleri: bir etkinlik örneği "maddenin halleri ve 1sı". VII. Ulusal Fen bilimleri ve Matematik Kongresi Bildiri özetleri kitabl, s:373, Ankara: Palme yayıncılık.

Fowler, F. J. (2009). Survey research methods (4th ed.). Thousand Oaks, CA: Sage. https://doi.org/10.4135/9781452230184

Gözütok, F. D. (2006). Öğretim ilke ve yöntemleri. Ankara: Ekinoks Yayınları.

Hamurcu, H. (2018). Examination of attitudes to learning and educational stress in prospective primary school teachers: İmir-Buca sample. Educational Research and Reviews, 13(2), 92-105. https://doi.org/10.5897/ERR2017.3431

Hamurcu, H., \& Canbulat, T. (2018). Öğretmen Adaylarının Öğretim Tekniklerinin Seçimine İlişkin Yeterlik Algıları, 10-12 Mayıs 2018 IASSR sunulan bildiri.

İçelli, O., Polat, R., \& Sülün, A. (2008). Fen eğitiminde yaratıcı drama desenleri. Ankara: Maya akademi.

İlter, İ. (2014). Öğretim elemanlarının kullandığı yöntem ve tekniklere ilişkin öğretmen adaylarının görüşleri. Uluslararası Sosyal Araştırmalar Dergisi, 7(35), 562- 576. 
Kabapınar, F. (2005). Yapılandırmacı öğrenme sürecine katkıları açısından fen derslerinde kullanılabilecek bir öğretim yöntemi olarak kavram karikatürleri. Kuram ve Uygulamada Eğitim Bilimleri, 5(1), 101-146.

Kaptan, F., \& Kuşakcı, F. (2002). Fen öğretiminde beyin firtınası tekniğinin öğrenci yaratıcılığına etkisi, V. Ulusal Fen Bilimleri ve Matematik Ĕ̈itimi Kongresi Bildiriler Kitabı, ss: 197-20, ODTÜ: Ankara.

Köklükaya, N. A., \& Yıldırım, E. G. (2018). Science Teacher Candidates' Expression Levels on the Expansion of Water Subject by Prediction- Observation- Explanation Method. Journal of Multidisciplinary Studies in Education, 2(1), 16-27

Korkmaz, H. (Ed.). (2004). Fen ve Teknoloji Eğitiminde Alternatif Değerlendirme Yaklaşımları. Ankara: Yeryüzü Yayınevi.

Kuşçu, E. (2017). Yabancı Dil Öğretimi/Öğreniminde Görsel Ve İşitsel Araçları Kullanmanın Önemi. Akademik Sosyal Araşttrmalar Dergisi, 43(5), 213-224. http://dx.doi.org/10.16992/ASOS.12106

MEB (2003). İlköğretim drama 1 (Öğretmen için). Üçüncü bask1, Ankara: Milli Eğitim Basımevi.

MEB (2013). İlkögrretim kurumları (İlkokullar ve ortaokullar) Fen Bilimleri dersi (3,4,5,6,7 ve 8. Sinıflar) ögretim programı. Ankara: T.C. Milli Eğitim Bakanlığı Talim Terbiye Kurulu Başkanlığı Yayını.

MEB (2017). Fen Bilimleri dersi ögretim programı (Ilkokul ve Ortaokul 3,4,5,6,7 ve 8. Sinıflar). Ankara:T.C. Milli Eğitim Bakanlığı Yayını.

Memiş R. M., \& Erdem, M. D. (2013). Yabancı Dil Öğretiminde Kullanılan Yöntemler, Kullanım Özellikleri ve Eleştiriler. Turkish Studies, 8(9), 297-318. http://dx.doi.org/10.7827/TurkishStudies.5089

Naylor, S., \& Keogh, B. (2011). Concept cartoons: what we have learnt?, World Conference on New Trends in Science Education (WCNTSE), Abstract book, p:32. İzmir. Dokuz Eylul University Printing Office.

Novak, J., \& Gowin, B. (1984). Learning how to learn. USA: Cambridge University Press. https://doi.org/10.1017/CBO9781139173469

Önder, A. (2003). Yaşayarak ögrenme için eğitici drama (5th ed.). Baskı, İstanbul: Epsilon yayıncılık.

Özer, B. (2013). Eğitim fakültesi son sınıf öğrencilerinin öğretim kuram, strateji yöntem ve tekniklerinin farkında olma ve kullanma düzeyleri. Mustafa Kemal Üniversitesi Sosyal Bilimler Enstitüsü Dergisi, 10(24), 197-211.

Özyılmaz Akamca, G., \& Hamurcu, H. (2005). "Çoklu Zeka Kuramı Tabanlı Öğretimin Öğrencilerin Fen Başarısı, Tutumları ve Hatırda Tutma Üzerindeki Etkileri. Hacettepe Üniversitesi Eğitim Fakültesi Dergisi, 28, 178-187.

Özyılmaz Akamca, G., \& Hamurcu, H. (2009). Analojiler, Kavram Karikatürleri Ve Tahmin-Gözlem-Açıklama Teknikleriyle Desteklenmiş Fen Ve Teknoloji Eğitimi. Education sciences (NWSA), 4(4), 1186-1206.

Özyılmaz Akamca, G., Ellez, A. M., \& Hamurcu, H. (2009). Effects Of Computer Aided Concept Cartoons On Learning Outcomes. Procedia Social and Behavioral Sciences, 1(1), 296-301. https://doi.org/10.1016/j.sbspro.2009.01.054

Saban, A. (2001). Çoklu Zeka Teorisi ve Ĕgitim. Ankara: Nobel yayınc1lı.

Şahbaz, Ö., \& Hamurcu, H. (2012). Probleme Dayalı Öğrenme ve İşbirlikli Öğrenme Yöntemlerinin Öğrencilerin Bilimsel Süreç Becerileri ve Öğrenme Çıtıları Üzerindeki Etkileri. Education Sciences (NWSA), 2(7), 734-754.

Şahin, D., \& Güven S. (2016). Sınıf Öğretmenlerinin Fen Bilimleri Hayat Bilgisi ve Sosyal Bilgiler Derslerindeki Yöntem ve Teknik Kullanımına İlişkin Görüşleri. Online Fen Eğitimi Dergisi, 1(1), 42-59.

Saracaloğlu, A. S., \& Karademir, Ç. (2009). Eğitsel oyun temelli fen ve teknoloji öğretiminin öğrenci başarısına etkisi. VIII. Ulusal Sınıf Öğretmenliği Ĕ̆itimi Sempozyumu, Bildiri Kitabı, 21-23.

Sayan, Y., \& Hamurcu, H. (2018). İlköğretim Fen Ve Teknoloji Dersi İçin Geliştirilen Materyallerin Öğrencilerin Yaratıcı Düşünme Becerilerine Ve Öz Kavramlarına Etkileri. Education Sciences (NWSAES), 13(2), 106-120.

Selçuk, Z., Kayıl1, H., \& Okut, L. (2002). Çoklu zeka uygulamaları. Ankara: Nobel yayıncılık.

Şimşek, H., Hırça, N., \& Coşkun, S. (2012). İlköğretim fen ve teknoloji öğretmenlerinin öğretim yöntem ve tekniklerini tercih ve uygulama düzeyleri: Şanlıurfa ili örneği. Mustafa Kemal Üniversitesi Sosyal Bilimler Enstitüsü Dergisi, 9(18), 249-268.

Sönmez, V. (2004). Dizgeli eğitim. Ankara: Anı Yayıncılık. 
Soylu, Y. (2009). Sınıf Öğretmen Adaylarının Matematik Derslerinde Öğretim Yöntem ve Teknikleri Kullanabilme Konusundaki Yeterlilikleri Üzerine Bir Çalışma. Mersin Üniversitesi Eğitim Fakültesi Dergisi, 5(1), 1-16.

Susar Kırmızı, F. (2007). Yaratıcı Drama Yönteminin Okuduğunu Anlama Başarısına Etkisi ve Yönteme İlişkin Öğrenci Görüşleri. Eğitim Araştırmaları (EJER), 29, 59-71.

Taşkaya, M. S., \& Muşta, C. M. (2008). Sınıf öğretmenlerinin Türkçe öğretim yöntemlerine ilişkin görüşleri. Elektronik sosyal bilimler dergisi (ESOSDER), 7(25), 240-251.

Taşpınar, M. (2016). Kuramdan uygulamaya öğretim ilke ve yöntemleri (8st ed.). Baskı. Ankara: Edge Akademi yayıncılık.

Üstündağ, T. (2000). Yaratıcı drama öğretmenimin günlüğü. Ankara: PEGEM A yayıncılık.

Yaprak, P., Hamurcu, H., \& Armağan, B. (2014). Sınıf Öğretmeni Adaylarının Durumluk Ve Sürekli Kaygı Düzeylerinin İncelenmesi (İzmir-Buca örneği). Bartın Üniversitesi Eğitim Fakültesi Dergisi, 3(2), 293-316. https://doi.org/10.14686/BUEFAD.201428183

Yıldırım, A., \& Şimşek, H. (2000). Sosyal Bilimlerde Nitel Araştırma Yöntemleri (2nd ed.). Baskı, Ankara: Seçkin yayıncilik.

Yıldırım, E. G., Köklükaya, A.N., \& Aydoğdu, M. (2016). Fen bilgisi öğretmen adaylarının öğretim yöntem - teknik tercihleri ve bu tercihlerinin nedenleri. e-Kafkas Eğitim Araştırmaları Dergisi, 3(1), 15-25.

Yılmaz K. T., \& Şaşmaz Ö. F. (2018). Kavram karikatürleriyle desteklenmiş bilimsel hikâyelerin akademik başarı, tutum ve motivasyon üzerine etkisi. Batı Anadolu Ĕ̌itim Bilimleri Dergisi, 9(1), 38-52.

Yılmaz, S. (2013). Sosyal bilgiler öğretiminde bir yöntem olarak dramanin kullanimina ilişkin öğretmen adaylarinin görüşleri. Ahi Evran Üniversitesi Kırşehir Eğitim Fakültesi Dergisi, 14(2), 123-145. 